\title{
THE CONTRIBUTION OF MEASUREMENT PROCESSES IN A TIME OF ECONOMIC CRISIS
}

\author{
Josef Veselý ${ }^{1}$, Lenka Černohorská ${ }^{2}$, Tomáš Kubala ${ }^{3}$, Pavel Juřica ${ }^{4}$ \\ ${ }^{1}$ Brno University of Technology, Faculty of Business and Management, Kolejni 2906/4, 61200 Brno \\ Email:vesely@fbm.vutbr.cz. \\ ${ }^{2}$ Brno University of Technology, Faculty of Business and Management, Kolejni 2906/4, 61200 Brno \\ Email:cernohorska@fbm.vutbr.cz \\ ${ }^{3}$ Brno University of Technology, Faculty of Business and Management, Kolejni 2906/4, 61200 Brno \\ Email:kubalatomas@email.cz \\ ${ }^{4}$ Brno University of Technology, Faculty of Business and Management, Kolejni 2906/4, 61200 Brno \\ Email:jurica@fbm.vutbr.cz
}

\begin{abstract}
This article refers to application of process control focusing on process measuring. It also emphasizes process measuring as an important approach of managers' models as the model EFQM and the model according to international standard ISO 9001. The contribution deals with evaluation and interpretation of data obtained by research at companies especially from the field of engineering, building industry and electrotechnics. During the analysis is used the classification of companies applied metrics into groups - perspectives applied by the methodology BSC. Coherences are analyzed between forwardness of measurement of companies' processes and their influence towards success of the organization. This research has proved the importance of managing processes for the organization success to a certain manner. Evincible dependency occurs between the level of process measurement at the company and its success at the market when the company has to face up problems coming from the contemporary economic crises is shown especially by the metric being used in the area of customer perspective.
\end{abstract}

Keywords: managers model, metric, process management, process measuring.

JEL classification: M11

Doručeno redakci: 30.6.2011; Recenzováno: 11.2.2013; 13.2.2013; Schváleno k publikování: 13.3.2013

\section{Introduction}

Starting from 1980 experts began to support radical changes in the ways corporate processes' efficiency were measured and controlled. As measurement based solely on financial indicators was subject to criticism, emphasis was put on usefulness of non-financial indicators (Kaplan, 1983).

In the early 1990s several methods were proposed for measurement of companies' efficiency. Universal models and approaches were put forward so as to be applicable to various types of organizations operating in various business environments. During this period authors focused on typical features of each organization. The most frequently cited authors of such methods are: (Dixon et al., 1990) efficiency measurement through questionnaires and efficiency measurement through enterprise model (Moriarity and Lewis, 1991), and Balanced Scorecard (Kaplan and Norton, 2000).

In the past two decades literature dealing with measuring output of corporate processes has emphasized several important features of the aforementioned methods. Some of them are listed below: 
- The methods must reflect relevant non-financial indicators based upon key factors of company's success (Clarke, 1995);

- They should be implemented as a means of organization's strategy (Reinstein and McWatters, 2000);

- They should be based upon company's goals, critical factors of success and upon customers' needs, including monitoring financial and non-financial aspects (Manoochehri, 1999);

- The methods must reflect requirements of particular situation in relevant production facilities, should be long-term oriented as well as easy to understand and implement (Santori and Anderson, 1987);

- The methods should stimulate further improvement of the processes (Kaplan and Norton, 2000).

\section{Process measurement in managerial models}

At present, companies commonly use a managerial model as formally defined by generic requirements outlined in ISO 9001 standard. The model puts emphasis on process control. Its "philosophy" is based upon " 8 principles of quality management". The fourth principle deals with process approach. The principle states that process management of all activities within an organization establishes conditions for effective use of resources, limits errors, and enables focus on continuous improvement. This basis resembles in a certain way another managerial model, namely the EFQM Excellence Model, later revised as the Excellence Model 2010. This model defines its "fundamental concepts" in a very similar way. While not as widely used and as popular as its counterpart, the EFQM Excellence Model also regards process approach as one of key factors.

Figure 1: The EFQM Excellence Model.

Enablers

Results

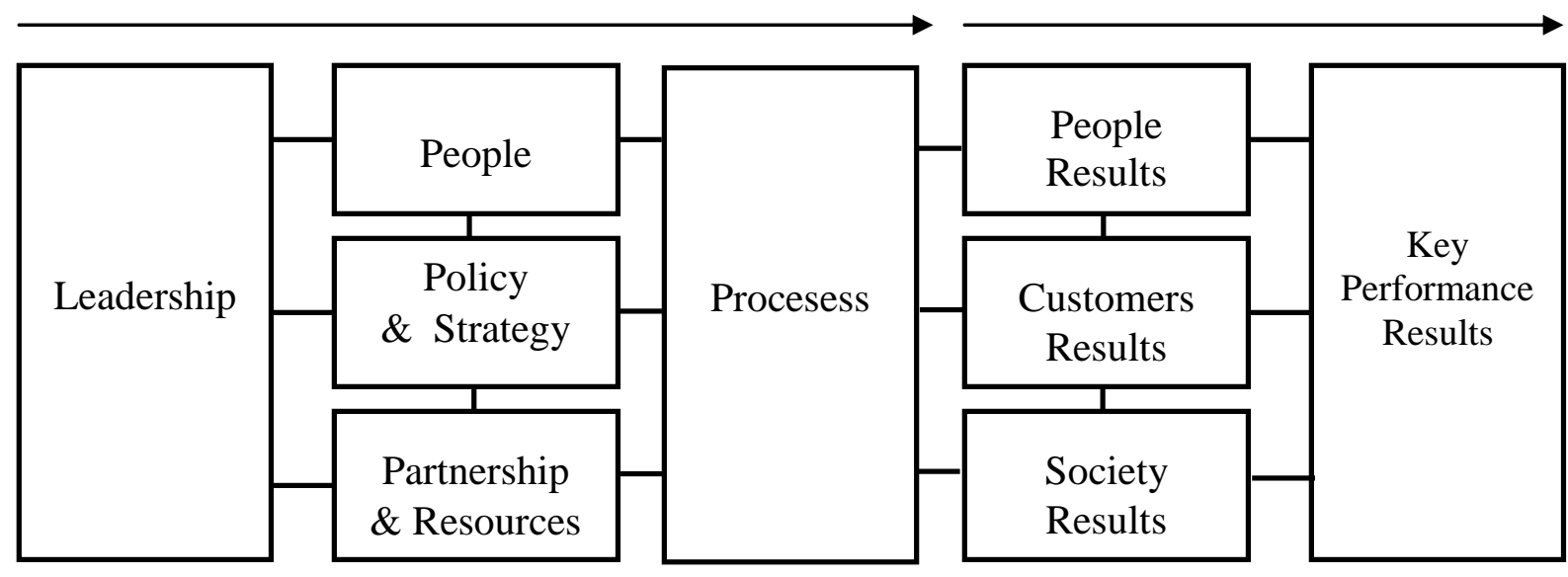

Inovation \& Learning

Source: according to Cliffe 2002.

Proper process management plays a key role in a successful application of the EFQM model as also evident from the EFQM visualization in which the "processes" criterion takes the central position. Processes are the most important of model's nine criteria. They are interlinked with antecedent and follow-up activities. There are exactly defined input and 
output parameters as well as their target values at the process input and output. All parameters are pre-defined and measurable.

Let's have a look at the EFQM Model (Fig. 1) in a slightly different way than most books and manuals (Cliffe, 2002).

Figure 2: EFQM Excellence Model.

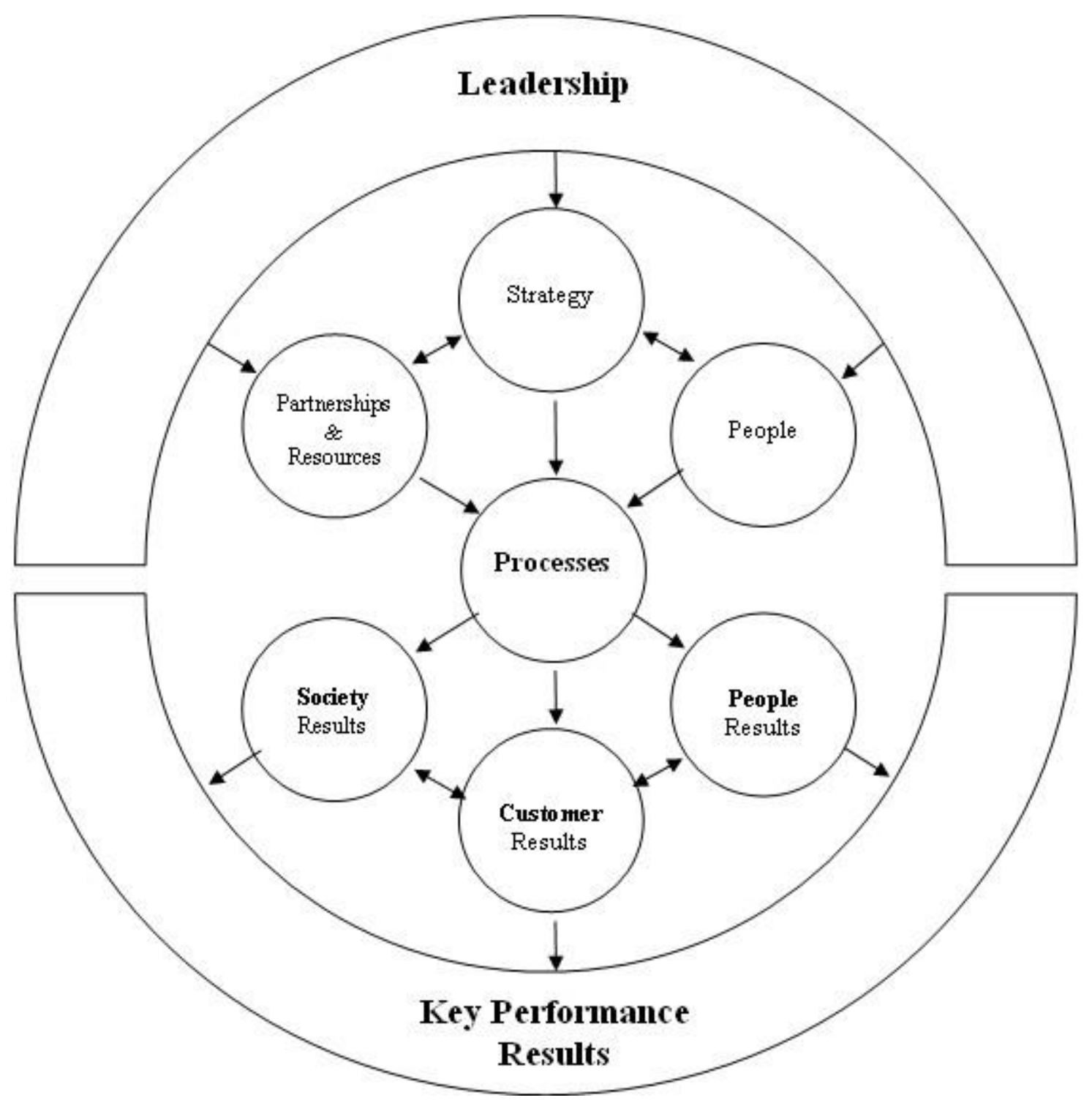

Source: authors' drawing (Veselý and Kubala, 2010).

When the traditional scheme is rearranged into a circular diagram (Fig. 2), the central position of approaches in process management for successful way to company's excellence stands out. The EFQM Model furthermore puts emphasis on the quality of process management which is underlined by the importance of criteria evaluating results achieved to considerable extent thanks to proper implementation of process management.

The ISO 9001 international standard, which is the basis for managerial models in numerous companies, also uses "process" as one of its key concepts and puts emphasis on their good formalization which is necessary for reliability of their function, repeatability, and 
effectiveness. Achieving set goals in terms of process output and effectiveness as well as in customer satisfaction plays an important role in the managerial model according to the ISO 9001 standard (ČSN EN ISO 9001:2009).

We assume that careful monitoring of process indicators is crucial for maintaining good economic results as well as corporate management during economic crisis.

\section{Methodology}

This research focuses on proving or rebutting of managerial process measurement importance for company's success. The recent economic crisis provided favourable conditions for confirming or rejecting the hypothesis that well-controlled processes based on proper measurement may assist the company in overcoming times of economic crisis.

Research data for this quantitative research was collected through questionnaires distributed in companies identified in advance. Questionnaires were filled during personal meetings with the managers and data collection took place in the course of 2010. The sample included 36 companies which agreed to provide relevant data. The research targeted at medium-sized manufacturing companies in the Czech Republic whose business environment offers suitable conditions for measuring output of company processes. Furthermore, a higher degree of process measurement formalization and its further use in management can be expected in such companies.

The research model used in this research is based upon experience of numerous successful companies that implemented in their management system process control together with process measurement. Managers frequently come to believe that company process output measurement provides a ground for correct decisions on future management of the company. The pivotal point of process management, namely process measurement, is promoted not only by good operation of companies, but also by successful implementation of the EFQM Excellence Model (Cliffe and Jung, 2002). Implementation of ISO 9001 international standard (ČSN EN ISO 9001:2009) is confirmed by numerous prominent authors in expert publications (Kumar, 2009; Collemen, 2003; Martin-Castilla, 2008).

The research model is derived from the fact that a company has a certain type of corporate management model. Such model should include measurement of set indicators used to assess operations within the company.

Our research model proposal was based upon four perspectives of the Balanced Scoreboard Method as put forward by Kaplan and Norton (Kaplan, 2000):

- Financial

- Customer

- Internal Business Processes

- Learning and Growth

To these perspectives company metrics were then attached.

The research model furthermore presumes that one of the factors providing for company's success during economic crisis might be advanced level of measuring processes it uses, i.e. quantity and quality of selected metrics as well as the extent to which measurement results are used in company process control. 
Figure 3: Companies by Sectors.

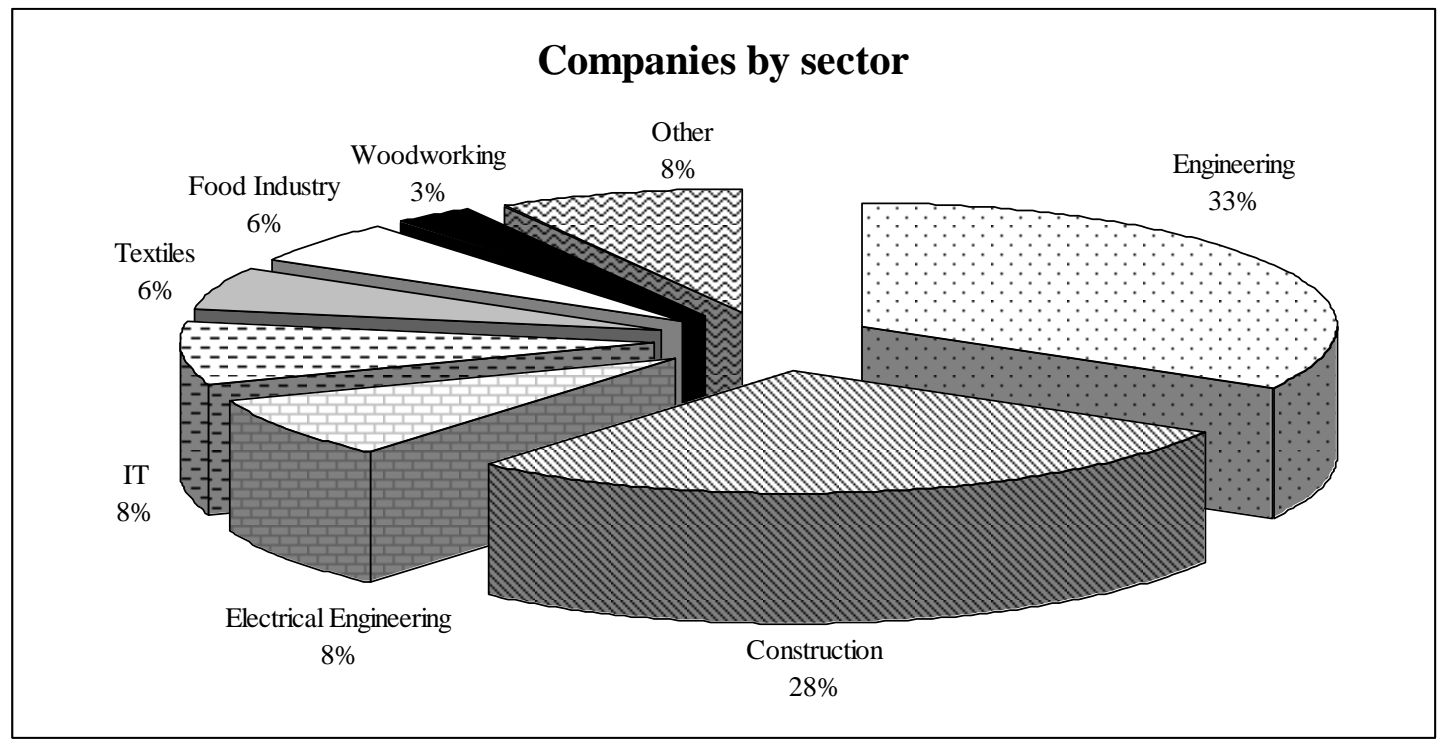

Source: authors' data.

The size of the companies that provided data was also taken into consideration in the research. All were small or medium-sized enterprises, i.e. up to 250 employees according to Directive (EC) 800/2008. The representation of the companies according to size can be seen in Fig. 4 .

Figure 4: Representation of Companies According to Number of Employees.

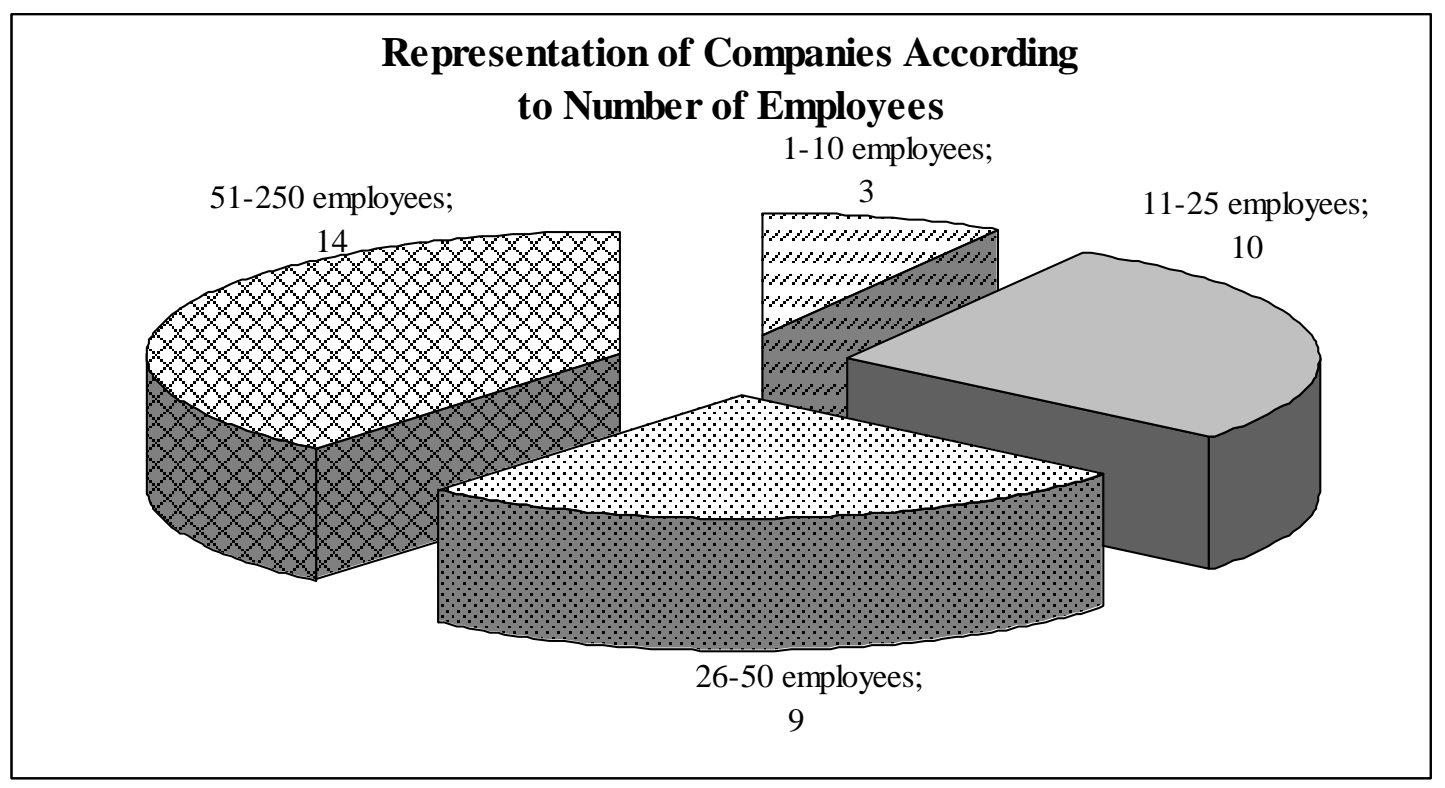

Source: authors' data.

The research analyzed measurable indicators that the companies use to control their processes and in effect the whole company as well. Depending upon the company's size, advanced level of management system, and industrial sector the companies listed a set of indicators that were subsequently divided into corresponding perspective categories stipulated by the Balanced Scoreboard methodology. 


\section{The most commonly used metrics in researched companies}

\section{Financial Perspective metrics:}

Return on sales, return on capital, liquidity, turnover ratio, claims, overdue claims, liabilities, cost, revenue, new customer revenue growth, profit, inventories, wages, return on investment, cash flow, operating cost, material cost, service cost, turnover time, debt ratio, trading margin, ROS, ROI, ROE, ROCE, EVA.

\section{Customer Perspective metrics:}

Number of regular customers, customer satisfaction, sales returns, customer loyalty, number of complaints, bidding success ratio, marketing presentation cost, market share, demand volume, client market share, customers paying in cash, customer's purchase frequency, new project value.

\section{Internal Business Processes Perspective metrics}

Inventory turnover period, number of sales returns per projects, rejects ratio, rejects cost, material consumption, average number of products per category, subcontractors evaluation index, production volume, machinery utilization, capacity utilization, equipment failure ratio, productivity, order fulfillment time, performance standard achievement ratio, production running time.

\section{Learning and Growth Perspective metrics}

Number of training courses, cost of employee training, number of training programs, employee education coefficient, number of employees, increase in number of employees, keeping employees, employee resignation ratio, employee sick leave ratio, employee absence from work ratio, job switching ratio, number of accidents, employee satisfaction, IS investment, average age, real wage increase, number of rejects per employee, length of experience, amount of bonuses.

Quality and quantity of the metrics used for process measuring in individual companies were evaluated on a scale. The particular value on the scale marked how advanced process measuring was. Numeric basis for the point evaluation was the number of metrics in particular perspective. In cases when circumstances such as context suggested that the number and selection of metrics used by a company suit its sector and size, one point was added to the total value acquired for the number of metrics. In cases of obviously limited relevance of some metrics a point was deducted from the total value.

The assessment of process measuring level by transformation into quantitative data based upon the number of metrics and their consequent qualitative correction aimed at a certain simplification of the task so as to enable statistic calculations and visualization.

Besides the level of process measuring, economic indicators during crisis were also monitored in researched companies. The indicators were then compared with the period preceding the economic crisis. The indicators included: profit, turnover, operational cost, market share, and new product revenue volume.

The companies could describe changes in the indicators on a scale with resolution of ten percentage points. These two types of company data allowed calculating relevant correlations. 


\section{Results}

The research model presumes there is a correlation between company's success during economic crisis and an advanced level of its process measuring. Above listed financial metrics and changes in them due to unfolding economic crisis were chosen as a success criterion (dependent variable).

Correlations between the level of process measuring and company's achievements or failures during economic crisis were observed. The data analysis revealed an interesting fact, namely that there is a demonstrable correlation between the advanced level of process measuring in a company and its market success when facing economic crisis, the correlation being particularly notable in customer perspective metrics. The fact is a logical consequence of mutual relationship between perspectives as good achieving in one perspective determines success in the following one. The cause and effect relationships are described by Kaplan and Norton (Kaplan 2000).

Metrics in the Customer Perspective directly affect company's success on the market. Metrics in the Internal Business Processes and Learning and Growth Perspectives create conditions for business success and its achievement. The most frequently found metric is "customer satisfaction" employed by 17 companies out of 36 researched. Similarly wide-spread metric is "complaints"; unfortunately, its further specifications - number of cases, percentage of production volume, or cost of resolving - are not available. Surprisingly metrics assessing innovation, providing new products to customers, preparation of new projects are used seldom. "New Project Value" metric was only used by two companies.

Among the achievements of the research there are lists of the most frequently used measurable indicators categorized by perspectives of the BSC methodology. Results of the inquiry in this field correspond with the real situation as known from everyday experience. The average point value of measuring processes' level was the highest in the Financial Perspective (3.94) which confirms field experience that companies most often monitor and asses indicators related to financial health, starting with the fact that the executive manager/owner checks account balance.

As the research primarily focused on manufacturing companies, the average point value of process measuring level in the Internal Business Processes Perspective (3.22) confirms that manufacturing companies generally employ a good system of production process control based upon data analysis acquired from measuring thereof.

The relatively good average value of measuring process' level in the Customer Perspective (2.92) is a pleasant surprise providing evidence that even actions in the business process area are managed according to data collected by measuring.

Fig. 5 illustrates the mutual relationship between average point value of measuring process level in the Customer Perspective (Customer Metrics) and companies' turnover. The other Fig. illustrate mutual relationships between average point value of measuring process level in the Customer Perspective and company's profit (Fig. 6), market share (Fig. 7), new product revenue (Fig. 8), and operational cost (Fig. 9). All the graphs display a considerable correlation between researched variables. Correlation coefficient of these dependencies exceeds 0.35 which the minimal acceptable value for a sample of 35 items. 
Figure 5: Turnover decrease/increase dependence on point value of process measuring.

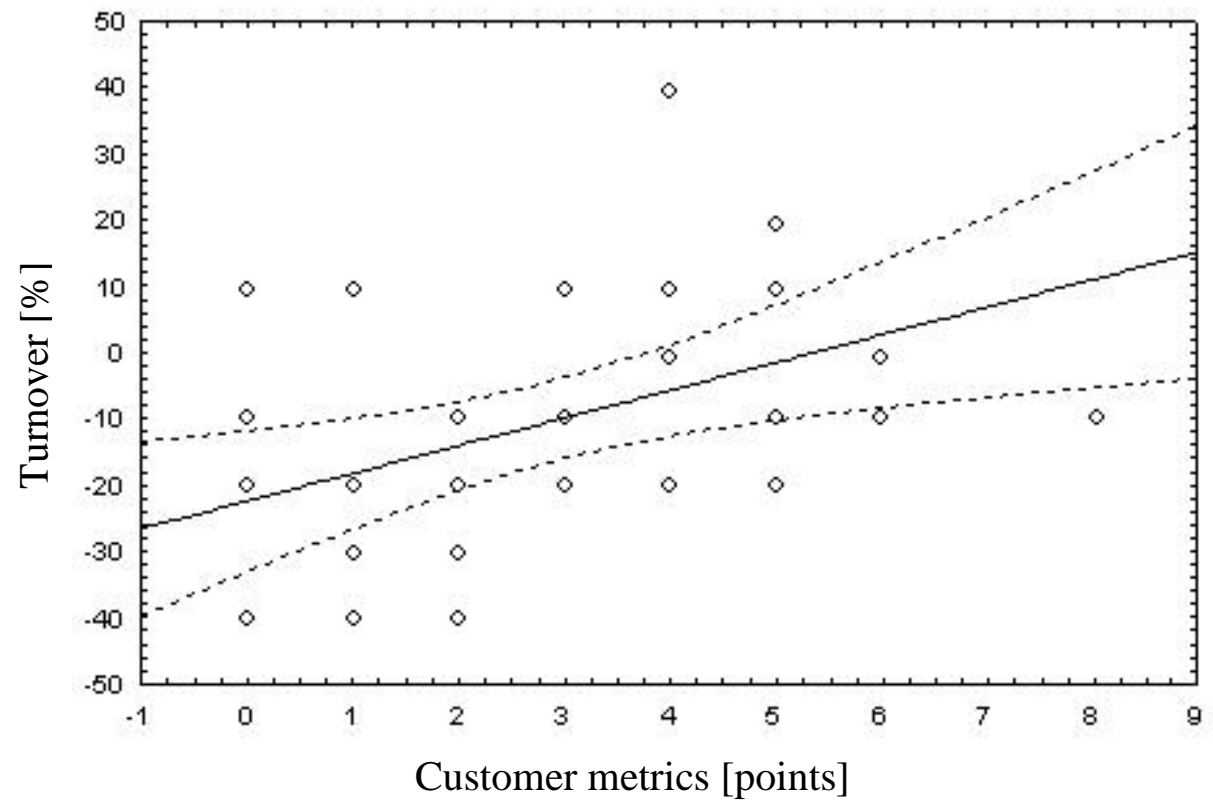

Source: authors' data.

Figure 6: Profit decrease/increase dependence on point value of process measuring.

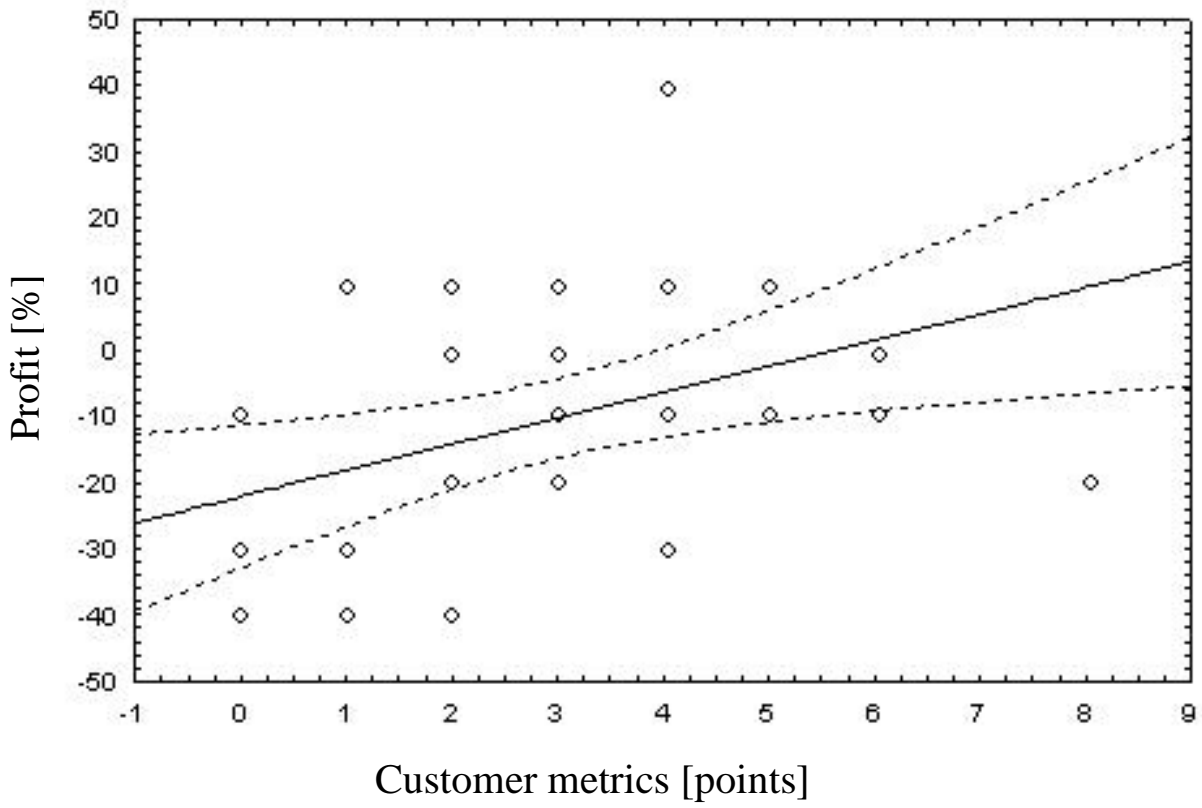

Source: authors' data. 
Figure 7: Market share decrease/increase dependence on point value of process measuring.

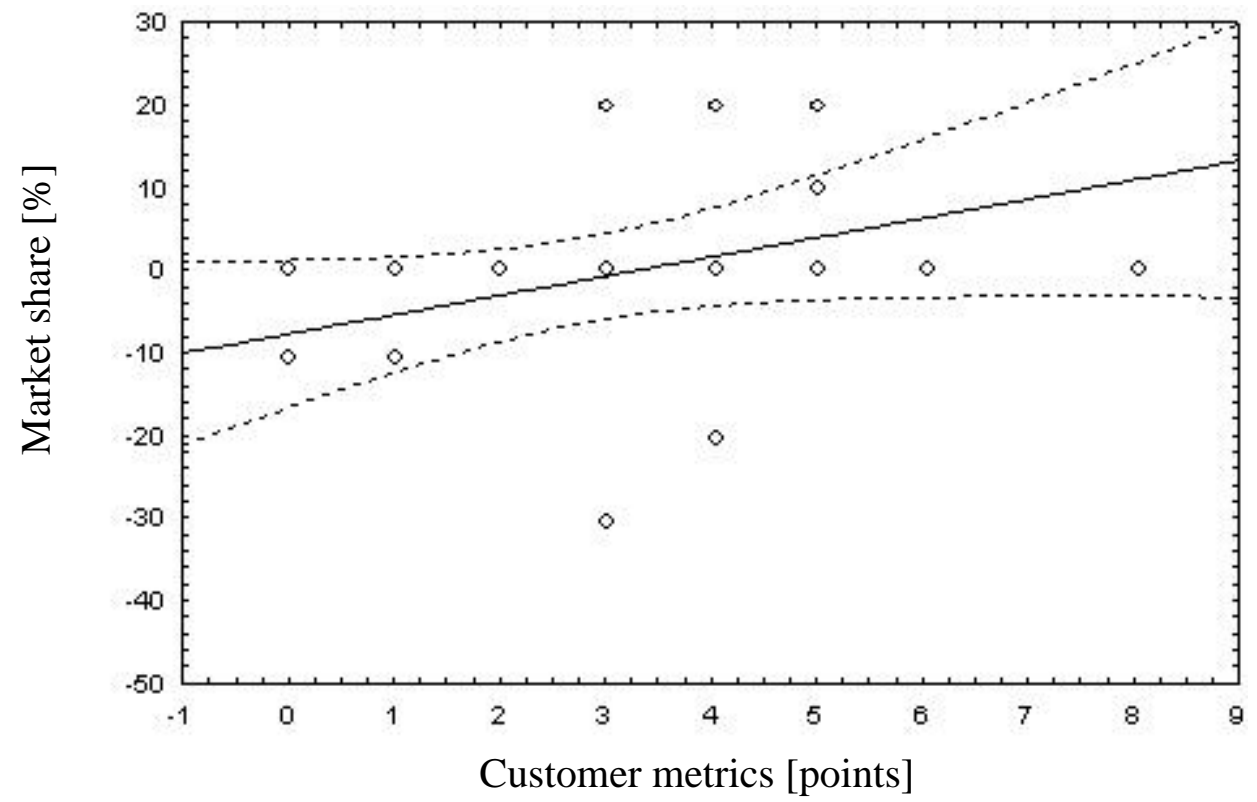

Source: authors' data.

Figure 8: New product revenue decrease/increase dependence on point value of process measuring.

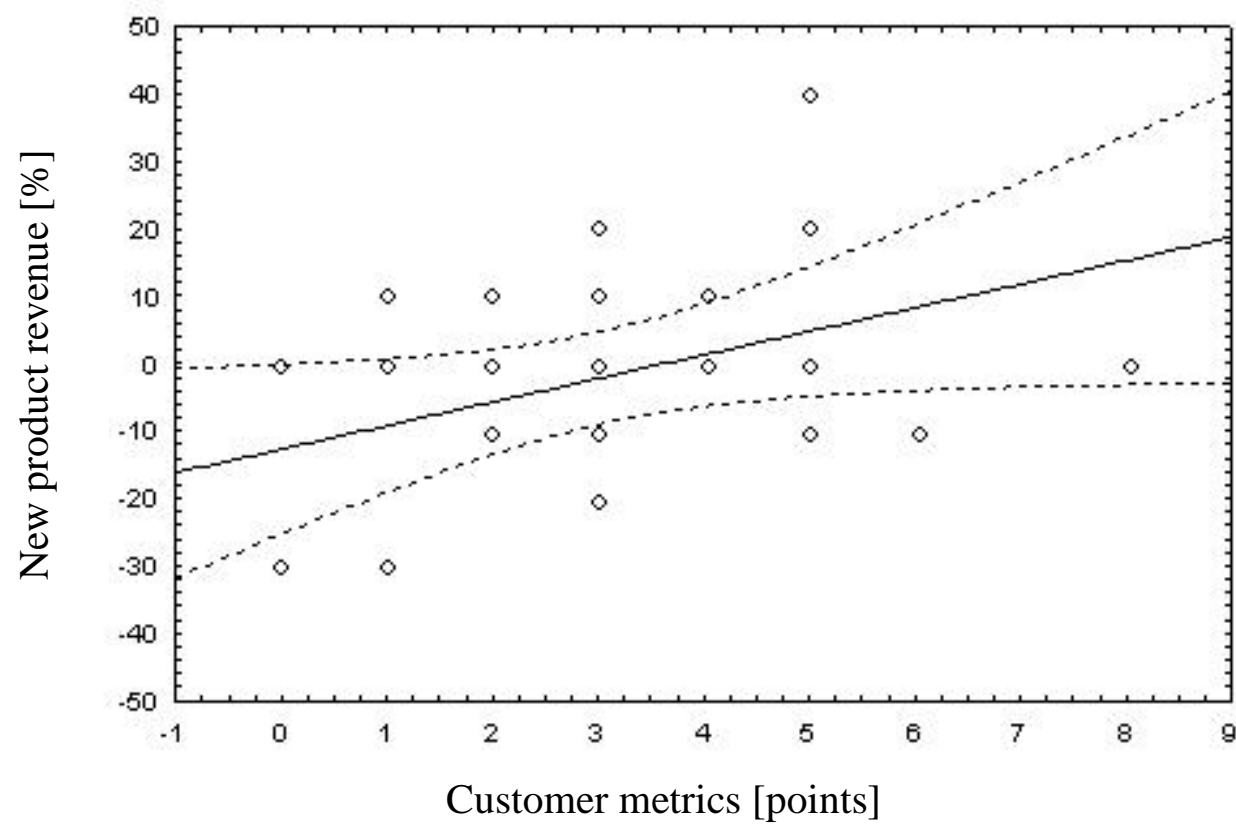

Source: authors' data. 
Figure 9: Operational cost decrease/increase dependence on point value of process measuring.

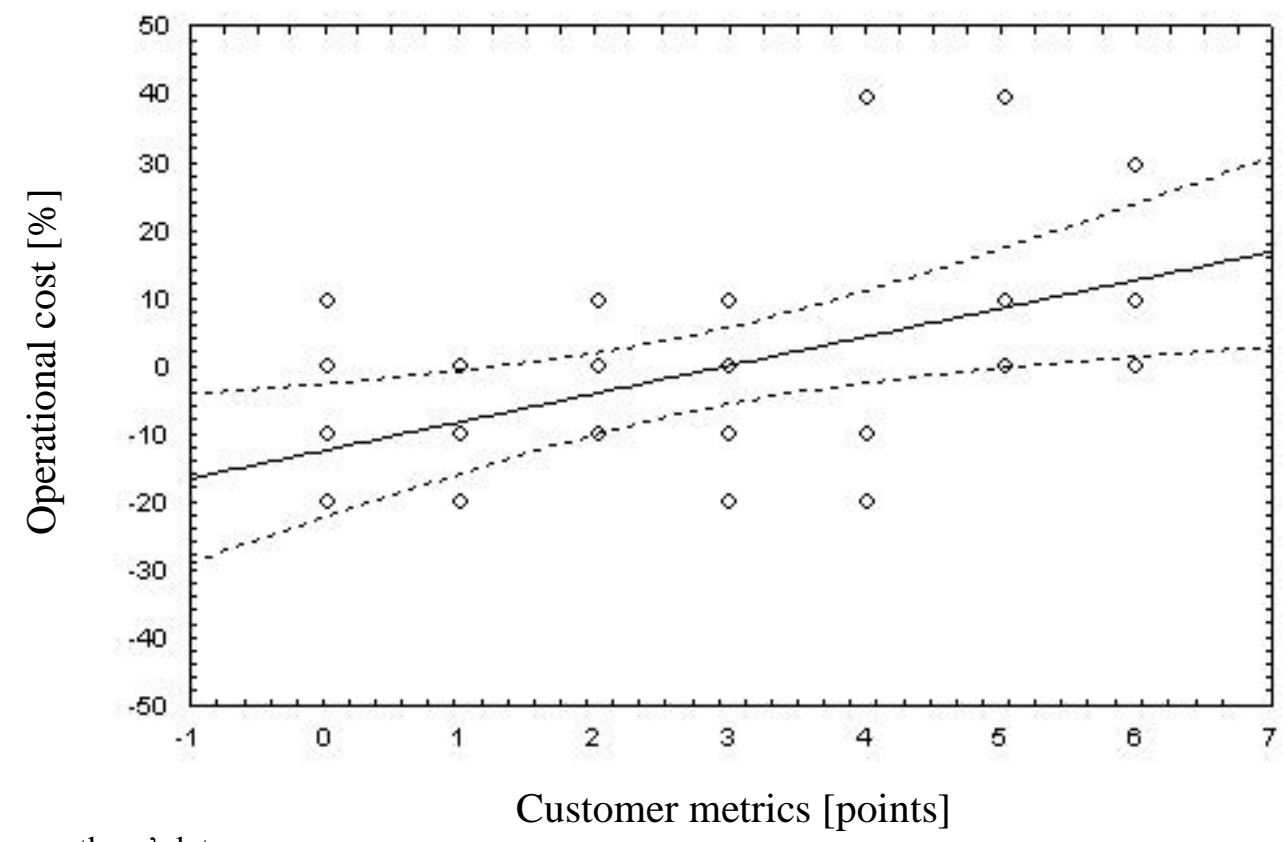

Source: authors' data.

\section{Conclusion}

The article contains information on research held in 2010. The research focused on the mutual relationship between how advanced the level of company measuring processes was and company's success. At present, the term "success" can also be understood as company's ability to withstand crisis and recover speedily after the expected end of crisis. This research is the first in the field and further development is anticipated.

The results above allow us to confirm the hypothesis that advanced company process measuring may be considered an important factor for company's success during economic crisis. The effort to measure company processes is proportional to company's achievements.

The most important finding is the demonstrated correlation between company's process measuring level and its market success when facing economic crisis. Metrics in the Customer Perspective play a particularly important role in measuring process outcome.

\section{References}

[1] CLARKE, P., 1995. Non-financial measures of performance in management, Accountancy Ireland. Vol. 27 No. 2, pp. 22-4.

[2] CLIFFE, R., M. JUNG, et all., 2003. Model excelence EFQM. 1. vydání. Praha: ČSJ Praha. 35s. ISBN 80-02-01572-X.

[3] CLIFFE R. et all., 2002. The Fundamental Concepts of Excellence. 1. vydání. Brussels: EFQM. 12 s. ISBN 90-5236-077-4.

[4] ČSN EN ISO 9001:2009 Systémy managementu kvality - Požadavky. Praha: Úřad pro technickou normalizaci, metrologii a státní zkušebnictví, 2009. 56 s. Třídící znak 01 0321 . 
[5] DIXON, J. R., A. J. NANNI and T. E. VOLLMANN, 1990. The New Performance Challenge: Measuring Operations for World-Class Competition. McGraw-Hill Professional Publishing. 199 s. ISBN 978-1556233012.

[6] KUMAR, V. et all., 2009. Impact of TQM on company's performance. Internationam Journal of Quality \&Reliability Management. Vol. 26, No. 1, pp. 23-37. Emerald 0265671X DOI 10.1108/02656710910924152.

[7] COLEMAN S. and A. DOUGLAS, 2003. Where next for ISO 9000 companies? The TQM Magazine. Vol. 15, No. 2, pp. 88-92. ISSN 0954-478X. DOI 10.1108/09544780310461099.

[8] MANOOCHEHRI, G., 1999. The road to manufacturing excellence: using performance measures to become world-class. Industrial Management. No.March-April, pp.7-13.

[9] MARTIN-CASTILLA, J. and O. RODRIGUEZ-RUIZ, 2008. EFQM model: knowledge governance and competitive advantage. Journal of Intellectual Capital. Vol. 9, No. 1, pp. 133-156, Emerald 1469-1930 DOI 10.1108/14691930810845858.

[10] MORIARITY, S. and R. LEWIS. Performance Measurement in Service Businesses. Accounting Review [serial on the Internet]. (1993, Jan), [cited February 8, 2011]; 68(1): 207-208. Available from: Business Source Complete.

[11] KAPLAN, R. Measuring Manufacturing Performance: A New Challenge for Managerial Accounting Research. Accounting Review [serial on the Internet]. (1983, Oct), [cited February 2, 2011]; 58(4): 686. Available from: Business Source Complete.

[12] KAPLAN, R. S. and D. P. NORTON, 2000. Balanced Scorecard. 1. vydání. Praha: Management Press. 267 s. ISBN 80-7261-032-5.

[13]REINSTEIN, A. and C. McWATTERS, (2000): Performance Measurement \& Control Systems for Implementing Strategy. Issues in Accounting Education [serial on the Internet]. (2000, Feb), [cited January 18, 2011]; 15(1): 163-164. Available from: Business Source Complete.

[14] SANTORI, P. and A. ANDERSON. Focus of Industry. Journal of Accountancy [serial on the Internet]. (1987, Nov), [cited February 11, 2011]; 164(5): 141-147. Available from: Business Source Complete.

[15] VESELÝ, J. a T. KUBALA, 2010. Měření procesů a jeho vliv na úspěšnost organizace. In Ekonomika a management podniki̊. Technická univerzita ve Zvolenu, Slovenská republika. ISBN: 978-80-228-2150- 6. 